\title{
EFEK PENYIMPANAN TERHADAP VIRULENSI NUCLEAR POLYHEDROSIS VIRUS YANG DIAPLIKASIKAN PADA TANAMAN KEDELAI TERSERANG ULAT GRAYAK (Spodoptera litura Fabr. )
}

\author{
Sudi Pramono ${ }^{1}$
}

\begin{abstract}
One of the problem increased soybean production was Spodoptera litura (army worm), because army worm has been known to be resistant to many insecticides. Alternatif control techniques should be explored to reduce population of the pest. Nuclear Polyhedrosis Virus (NPV) could storage one or more year, but must used technique cold storage so that not virulence decreased. This experiment was conducted to study (1) NPV pathogenicity to army worm in the field, and (2) the effect of storage on the pathogenicity of NPV to $S$. litura. The research consisted of two experiments i.e. laboratory and field experiments. Each experiment had seven treatments arranged in a randomized completely block design. Each treatment was replicated four times. The results show the highest mortality of $S$. litura occurred in plot treated with $1,0 \mathrm{x}$ $10^{7} \mathrm{PIBs} / \mathrm{ml}$, the mortality was 48 to $49,33 \mathrm{spec} / \mathrm{plot}$ after ten days aplicated. If comparative patogenicity the new and the old NPV was not significant. Population of army worm decreased significantly by NPV and control. So that patogenecity NPV storage one year as well as new NPV against army worm.
\end{abstract}

Kata kunci : NPV, Spodoptera litura

\section{PENDAHULUAN}

Usaha pengembangan dan peningkatan produksi produksi kedelai sampai tahun 1997 dapat dikatakan kurang memuaskan sehingga Indonesia masih mengimpor kedelai 423.860,946 ton (Biro Pusat Statistik, 1997). Salah satu faktor yang seringkali menjadi kendala adalah adanya serangan organisme pengganggu tanaman (OPT) khususnya hama dan penyakit tanaman. Kehilangan hasil ditentukan oleh tinggi rendahnya populasi , bagian tanaman yang terserang, intensitas serangan, tanggapan tanaman terhadap gangguan kerusakan, fase pertumbuhan tanaman, varietas yang ditanam, budidaya tanaman, dan tindakan pengendalian yang dilakukan oleh petani (Direktorat Bina Perlindungan Tanaman, 1994).

Salah satu hama utama tanaman kedelai adalah Spodoptera litura F. (Lepidoptera; Noctuidae), yang merusak tanaman kedelai sejak fase vegetatif sampai fase generatif. Larva yang baru keluar dari telur hidup bergerombol di permukaan bawah daun dan menggerogoti epidermis daun. Larva instar kedua atau ketiga hanya memakan helaian daun dengan meninggalkan tulang-tulang daun. Namun pada instar keempat dan kelima dapat memakan seluruh daun sampai tulang-tulang daunnya (Harahap, 1994).

Menurut Untung (1993) ulat grayak sudah resisten terhadap berbagai jenis racun seperti endosulfan, permetrin, sipermetrin dan dekametrin. Sejalan dengan hal tersebut maka perlu dikembangkan cara pengendalian lain, seperti penggunaan patogen serangga. Salah satu patogen serangga yang potensial dari golongan virus adalah Nuclear Polyhedrosis Virus (NPV).

NPV telah digunakan dalam uji coba lapangan dan kebanyakan memberikan hasil yang sangat memuaskan (Huffaker dan Messenger, 1989). NPV dapat menginfeksi Spodoptera spp. dan menekan populasi Spodoptera litura sehingga tidak menimbulkan kerusakan berat pada daun kedelai.

Faktor yang menentukan tingkat keefektivan virus antara lain sifat, konsentrasi, cara aplikasi dan tingkat persistensinya di lapangan. Inokulum NPV bersifat resisten apabila disimpan di dalam lemari pendingin dalam bentuk polyhedra kering. Preparat polyhedrosis biasanya bertahan selama empat sampai lima tahun, granulosis selama dua hingga tiga tahun, dan polyhedrosis cytoplasmic bertahan selama satu tahun (Angus dan Luthy, 1971 dalam Huffaker dan Messenger, 1989). Setelah diaplikasikan di lapangan

\footnotetext{
${ }^{1}$ Dosen Jurusan Proteksi Tanaman, Fakultas Pertanian Universitas Lampung
} 
apabila tidak terkena sinar matahari secara langsung dapat bertahan lama, tetapi apabila secara langsung terkena sinar terus menerus maka setiap hari virulensinya berkurang 50 persen.

Penelitian ini bertujuan untuk membandingkan efek Nuclear Polyhedrosis Virus (NPV) yang sudah disimpan lama (satu tahun) dibandingkan dengan NPV yang baru dibiakkan secara in vivo S. litura.

\section{BAHAN DAN METODE}

Penelitian ini telah dilaksanakan di Laboratorium Hama dan Penyakit Tanaman, Jurusan Proteksi Tanaman, Fakultas Pertanian, Universitas Lampung, dan Field Training Facilities (FTF) Trimurjo, Lampung Tengah, dari bulan November 1998 sampai dengan bulan Februari 1999.

Percobaan disusun dalam rancangan kelompok teracak sempurna (RKTS), dengan 7 perlakuan masing-masing 3 ulangan. Setiap petak perlakuan berukuran $3 \mathrm{~m}$ x $3 \mathrm{~m}$, antar petak terok berjarak $1 \mathrm{~m}$ dan antarkelompok $1,5 \mathrm{~m}$. Perlakuan terdiri dari kontrol, NPV lama pada konsentrasi 1,0 x $10^{3}$ PIBs/ml; $1,0 \times 10^{5} \mathrm{PIBs} / \mathrm{ml} ; 1,0 \times 10^{7} \mathrm{PIBs} / \mathrm{ml}$ dan NPV baru (hasil perbanyakan) masing-masing dengan konsentrasi $1,0 \times 10^{3} \mathrm{PIBs} / \mathrm{ml} ; 1,0 \times 10^{5} \mathrm{PIBs} / \mathrm{ml}$ dan $1,0 \times 10^{7} \mathrm{PIBs} / \mathrm{ml}$.

Pengamatan dilakukan setiap dua hari sampai hari kesepuluh, parameter berupa yang diamati adalah mortalitas $S$. litura tersebab NPV dan tingkat kerusakan daun kedelai pada setiap petak percobaan. Pengamatan terhadap mortalitas larva dilakukan dengan cara menghitung langsung larva S. litura yang ditemukan mati tersebab NPV pada setiap petak perlakuan. Tingkat kerusakan daun dihitung dengan menggunakan rumus intensitas kerusakan, yaitu:

$$
I=\frac{\sum(\mathrm{n} \cdot \mathrm{v})}{(\mathrm{N} \cdot \mathrm{V})} \times 100 \%
$$

dengan $\quad \mathrm{I}=$ Intensitas kerusakan daun $\mathrm{N}=$ Jumlah rumpun yang diamati

$\mathrm{V}=$ Harga numerik dari tiap kategori kerusakan daun dalam rumpun

$\mathrm{v}=$ Harga numerik kategori kerusakan tertinggi

$\mathrm{n}=$ Jumlah rumpun dari tiap kategori kerusakan

Data yang diperoleh dianalisis dengan sidik ragam kemudian dilanjutkan dengan pemisahan nilai tengah menggunakan uji jarak berganda Duncan (UJBD) pada taraf 5\%.

\section{HASIL DAN PEMBAHASAN}

\section{Mortalitas Spodoptera litura Fabr.}

Mortalitas larva S. litura mulai terjadi pada hari keempat setelah aplikasi, sedangkan hari sebelumnya baru tampak gejala yang diperlihatkan oleh larva yang terinfeksi virus yaitu gerakan larva lamban, permukaan kulitnya mengkilat dan agak membengkak. Pada bagian ventral berwarna putih susu, seperti terjadi akumulasi cairan putih. Larva yang bergejala ini, jika disentuh malas bergerak, akhirnya pecah dan mengeluarkan cairan kental berwarna putih susu. Menurut Indrayani dan Gothama (1991), cairan kental tersebut mengandung jutaan polyhedral inclusion bodies (PIBs). Menurut Payne dan Mortants dalam Fuxa dan Tanada (1987), sel-sel epitel usus inang pecah secara sempurna dan mengeluarkan feces yang terkontaminasi virus. NPV dapat mematikan larva $S$. litura pada tiga hari setelah aplikasi (hsa). Setelah hari keempat tingkat mortalitas secara komulatif terus meningkat sampai hari kesepuluh, dari hasil pengujian tampak bahwa penyimpanan selama satu tahun tidak memberi pengaruh terhadap tingkat virulensi NPV terhadap larva. Peningkatan mortalitas terjadi pada konsentrasi yang lebih tinggi, tingkat mortalitas tertinggi pada hari kesepuluh dengan perlakuan NPV pada konsentrasi $1,0 \times 10^{7} \mathrm{PIBs} / \mathrm{ml}$, hasil selengkapnya dapat dilihat pada Tabel 1 .

Dari pengujian statistik pada hari kesepuluh setelah aplikasi diperoleh hasil yang sangat signifikan antara perlakuan dibandingkan dengan kontrol. Tingkat mortalitas tertinggi pada perlakuan NPV dengan konsentrasi 1,0 x $10^{7} \mathrm{PIBs} / \mathrm{ml}$. NPV yang telah disimpan dibandingkan dengan NPV baru tidak menunjukkan perbedaan, kedua-duanya mempunyai virulensi yang sama. Hasil yang lebih jelas dapat dilihat pada Gambar 1. Dengan demikian dapat dikatakan bahwa penyimpanan selama satu tahun tidak menurunkan tingkat virulensi NPV. Hal ini didukung pendapat peneliti Balitsa Lembang yang telah mengemas NPV dicampur dengan talk kemudian ditempatkan pada botol plastik mampklu disimpan sampai satu tahun lebih. Menurut Mangundihardjo (1993), kelemahan NPV yang disimpan lama karena 
selama dalam penyimpanan virus tidak menemukan inang memerlukan waktu untuk aktif mendapatkan jaringan/sel hidup maka aktivitasnya kembali.

berhenti dan mengkristal sehingga apabila

Tabel 1. Tingkat mortalitas larva S. litura tersebab NPV

\begin{tabular}{|c|c|c|c|c|}
\hline \multicolumn{2}{|c|}{ Perlakuan } & \multicolumn{2}{|c|}{ Mortalitas (ekor/petak) } & \multirow[b]{2}{*}{10 hsa } \\
\hline & 4 has & $6 \mathrm{hsa}$ & 8 has & \\
\hline P1 & 1,25 & 1,25 & 1,25 & 1,25 \\
\hline P2 & 7,50 & 20,00 & 26,25 & 26,25 \\
\hline P3 & 7,11 & 23,11 & 28,44 & 29,77 \\
\hline P4 & 11,55 & 34,22 & 45,33 & 48,00 \\
\hline P5 & 7,33 & 22,00 & 27,33 & 28,00 \\
\hline P6 & 9,33 & 26,33 & 26,33 & 29,33 \\
\hline P7 & 11,33 & 34,66 & 46,66 & 49,33 \\
\hline
\end{tabular}

Keterangan : $\quad \mathrm{P} 1=$ kontrol, $\mathrm{P} 2=\mathrm{NPV}$ lama dengan konsentrasi $1,0 \times 10^{3} \mathrm{PIBs} / \mathrm{ml}$, P3 = NPV lama dengan konsentrasi 1,0 x 10 $\mathrm{PIBs} / \mathrm{ml}, \mathrm{P} 4=\mathrm{NPV}$ lama dengan konsentrasi 1,0 x $10^{7} \mathrm{PIBs} / \mathrm{ml}, \mathrm{P} 5=\mathrm{NPV}$ baru dengan konsentrasi $1,0 \times 10^{3} \mathrm{PIBs} / \mathrm{ml}$, P6 = NPV baru dengan konsentrasi 1,0 x $10^{5} \mathrm{PIBs} / \mathrm{ml}$,

P7 = NPV baru dengan konsentrasi $1,0 \times 10^{7} \mathrm{PIBs} / \mathrm{ml}$, hsa $=$ hari setelah aplikasi

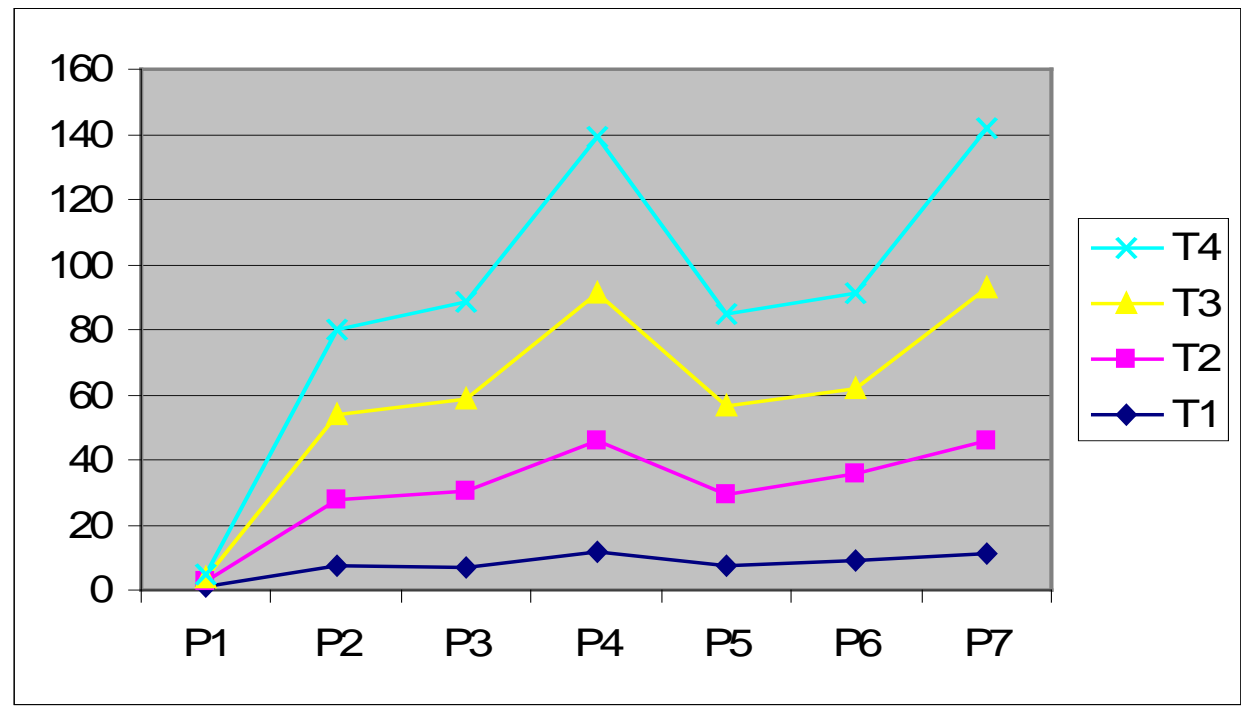

Gambar 1. Grafik tingkat mortalitas ulat grayak pada berbagai konsentrasi

P1, P2, P3, P4, P5, P6, P7 = perlakuan seperti Tabel 1., T1 = tingkat mortalitas ulat 4 hari setelah aplikasi, T2 = tingkat mortalitas ulat 6 hari setelah aplikasi, T3 = tingkat mortalitas ulat 8 hari setelah aplikasi, $\mathrm{T} 4=$ tingkat mortalitas ulat 10 hari setelah aplikasi

\section{SIMPULAN}

Dari hasil penelitian dapat disimpulkan sebagai berikut: (1) Lama penyimpanan tidak perpengaruh terhadap virulensi NPV, yang menentukan tingkat mortalitas ulat grayak adalah konsentrasi NPV yang diaplikasikan. (2) Perbedaan konsentrasi NPV berpengaruh nyata terhadap mortalitas S.litura, 
konsentrasi 1,0 x $10^{7} \mathrm{PIBs} / \mathrm{ml}$ menimbulkan mortalitas tertinggi yaitu 48 -- 49,33 ekor per petak.

\section{DAFTAR PUSTAKA}

Arifin, M. 1987. Pengaruh Konsentrasi dan Volume Nuclear Polyhedrosis Virus terhadap Kematian Ulat Grayak Kedelai (Spodoptera litura F.). Penelitian Pertanian Vol. 8 No. 1. 1998. Badan Penelitian dan Pengembangan Pertanian. Balai Penelitian Tanaman Pangan. Bogor. hlm. 12-14.

Direktorat Jenderal Pengendalian Tanaman Pangan dan Hortikultura. 1994. Rekomendasi Pengendalian Hama dan Penyakit Tanaman Pangan dan Hortikultura. Direktorat Bina Perlindungan Tanaman. $176 \mathrm{hlm}$.

Fuxa, J.R. dan Tanada, Y.. 1987. Epizootiology of Insect Diseases. John Wiley dan Sons. New York. $555 \mathrm{p}$.

Gothama, A.A.A. dan Idrayani, I.G.A.A. 1991. Potensi NPV sebagai Agensia Hayati Pengendali Helicoverpa armigera pada Tanaman Kapas. Jurnal Litbang Pertanian. hlm. 8-10.
Huffaker, C.B. dan Messenger, P.S.. 1989. Teori dan Praktik Pengendalian Biologis. Penerbit Universitas Indonesia. Jakarta. $352 \mathrm{hlm}$.

Harahap, I.S. 1994. Hama Palawija. Penebar Swadaya. $95 \mathrm{hlm}$.

Indrayani, I.G.A.A. dan Subijakto. 1994. Prospek Penggunaan Nuclear Polyhedrosis Virus (NPV) untuk Pengendalian Ulat Buah, Helicoverpa armigera dan Ulat Grayak, Spodoptera litura. Balai Penelitian Tembakau dan Tanaman Serat. Jurnal Litbang Pertanian XIII (4). hlm. 106-110.

Mangoendihardjo, S., Wagiman, dan Wijonarko, Arman. 1992. Penggunaan Nuclear Polyhedrosis Virus (NPV) dalam Pengendalian Ulat Grayak (Spodoptera litura Fabr.) dan Pemakan Bunga serta Polong (Helicoverpa armigera Hbn.) pada Kedelai. Laporan Akhir Penelitian Pendukung PHT dalam Rangka Pelaksanaan Program Nasional PHT. Proyek Kerjasama antara Fakultas Pertanian UGM Yogyakarta dengan Bappenas. $28 \mathrm{hlm}$. 